\title{
Effect of Extra Panadol on Blood and Behavior of Rats
}

\author{
Nazish Waris', Rana Kausar ${ }^{*}$, Nazish Waris ${ }^{2}$, Farina $\mathrm{Naz}^{2}$ and Asfia Raza ${ }^{2}$
}

${ }^{1}$ Baqai Institute of Diabetology and Endocrinology, Karachi, Pakistan

${ }^{2}$ Federal Urdu University of Arts, Science and Technology, Karachi, Pakistan

\begin{abstract}
Aim: To study the effect of Panadol extra on blood and behavior of rats

Methods: Locally bred male albino Wister rats weighing about 145 to $155 \mathrm{~g}$ on arrival purchased from animal house, research institute of Agha Khan University Karachi Pakistan were used throughout the experiments. Total of 24 rats were grouped into two: 12 rats called control and 12 test group. Normal saline was given to control while, $500 \mathrm{mg} /$ tablet (extra Panadol) into $30 \mathrm{mg} / \mathrm{kg}$ body weight was dissolved in water and was given to rats. Behavioral study was observed. After 3 weeks of treatment rats were decapitated. Automated Hematology Analyzer SYSMEX XP 100 and Biochemical analyzer the Roche/Hitachi 902 was used for liver enzymes and hematological analysis.
\end{abstract}

Results: Panadol extra has no effect on locomotor activity and the effect of stimulatory activity of rats increases. Depression and anxiety of rats decreases and at the same time it is useful to enhance memory. Hematological parameters and liver enzymes were also non-significantly decreased in test group of rats as compare to control group. Panadol extra is considered a good choice of drug and its side effects are very rare if it is used properly but by frequent and prolonged or excessive use of Panadol extra rats become unable to Fight against diseases and it also highly significantly decreases the PLT count by which their blood clotting mechanism is highly disturbed.

Conclusion: Present study concludes that this drug may be used to enhance memory and decrease anxiety and depression for good performance.

Keywords: Panadol extra; Depression; Anxiety; Memory

\section{Introduction}

Plant-derived compounds have mostly significant anti-inflammatory and anti-nociceptive effects [1]. It was estimated that about $40 \%$ of all medicines have been derived directly or indirectly from natural sources in the market today, $25 \%$ being from plants, $13 \%$ from micro-organisms and $3 \%$ from animals [2]. Some relevant examples of drugs derived from natural sources are also found in the market [3]. Analgesic drugs act in various ways on the peripheral and central nervous systems [4]. These include paracetamol, the Non-Steroidal Anti-Inflammatory Drugs (NSAIDs) such as the salicylates, and opioid drugs such as morphine and oxycodone [5]. The opioid analgesics can be used for either short-term or long-term relief of severe pain [6]. The evidence is described for the probability of the activity exhibited by analgesics and their antagonists being due to their association with a specific receptor surface.

Previously, clinical results of paracetamol with phenacetin were also reported, another aniline derivative. It was claimed that, unlike phenacetin, paracetamol had a slight tendency to produce methemoglobinemia [7]. Paracetamol was then quickly discarded in favor of phenacetin. In another study, it was also reported that large doses of paracetamol given to albino rats did not cause methemoglobinemia [8]. It was suggested that methemoglobinemia is produced in humans mainly by another metabolite, phenyl hydroxylamine [9]. Since then as an analgesic agent with few side-effects and little interaction with other pharmaceutical agents, Paracetamol was then added to the British Pharmacopoeia and has gained popularity. Caffeine acts as a natural pesticide and commonly consumed by humans in infusions. Caffeine in humans acts as a central nervous system stimulant, temporarily warding off drowsiness and restoring alertness [10].

Panadol extra which is also an analgesic drug. Panadol extra soluble tablets contain two active ingredients, paracetamol and caffeine [11].
Paracetamol as known is a simple painkilling medicine used to relieve mild to moderate pain and fever. Despite its widespread use for over 100 years, it was not fully understood that how paracetamol works to relieve pain and reduce fever [12]. However, it is now thought that it works by reducing the production of prostaglandins in the brain and spinal cord. The caffeine in Panadol Extra can cause anxiety and sleeplessness, but this is very rare when Panadol Extra is used correctly. However, it is more likely to get these side effects if subject consume caffeine-containing food and drinks when taking Panadol Extra. Panadol Extra is taken to help to relieve pain. It can be used to relieve pain that is short-term, for instance, after having a tooth removed. Other types of short-term pain that Panadol Extra can be used to treat include: headache and migraine, cold and flu symptoms (paracetamol also reduces fever), muscle aches, sore throat, period pain, joint pain caused by arthritis [13]. The purpose of the present study was to determine the effect of Panadol extra on blood and behavior of rats.

\section{Methods}

Total of 24 rats used in this study, in which 12 rats are control and 12 test group. Locally bred male albino Wister rats weighing about 145 to $155 \mathrm{~g}$ on arrival purchased from animal house, research institute

*Corresponding author: Rana Kausar, Associate Professor, Department of Biochemistry, Federal Urdu University of Arts, Science and Technology, Karachi, Pakistan, Tel: 0333 3404812; E-mail: ahamza286@gmail.com

Received June 23, 2017; Accepted July 28, 2017; Published August 04, 2017

Citation: Waris N, Kausar R, Waris N, Naz F, Raza A (2017) Effect of Extra Panado on Blood and Behavior of Rats. J Bioanal Biomed 9: 206-211. doi:10.4172/1948593X.1000179

Copyright: @ 2017 Waris N, et al. This is an open-access article distributed under the terms of the Creative Commons Attribution License, which permits unrestricted use, distribution, and reproduction in any medium, provided the original author and source are credited. 
of Agha Khan University Karachi Pakistan was used throughout the experiments. The rates were housed individually in specially designed cages with saw dust cover floor in a quiet room, with free access to cubes of standard rat's food and water for at least, four days before starting the experiment. So that the rats could adapted them, to the new environment.

\section{Oral administration of drug}

Control rats were given saline while $500 \mathrm{mg} /$ tablet extra Panadol was dissolved in water and $30 \mathrm{mg} / \mathrm{kg}$ body weight was given to test rats. For the preparation of saline $4.5 \mathrm{~g} \mathrm{NaCl}$ was dissolved in $500 \mathrm{ml}$ water and then, it was freezed to get chilled saline. After 1st, 2nd and 3rd weeks of treatment different behavioral experiments were performed.

\section{Behavioral activity}

The light-dark apparatus consists of two-compartment chamber (40 $\times 60 \times 20 \mathrm{~cm})$ comprising of a brightly illuminated area $(40 \times 40 \mathrm{~cm})$ and a dark area $(40 \times 20 \mathrm{~cm})$ separated by a wall with a round hole $(7$ $\mathrm{cm}$ diameter). Mice were placed individually in the illuminated part of the cage and following parameters were recorded during the test session of $5 \mathrm{~min}$, total no. of crossing between the light and dark area, total time spent in the illuminated part of the cage. Drug-induced increases in behaviors in the white part of a two-compartment box are suggested as an index of anxiolytic activity. Home cage $(26 \times 26 \times 26 \mathrm{~cm})$ with saw dust covered floor was used for grooming and gnawing activity. The open field apparatus with $72 \times 72 \mathrm{~cm}$ used for the novel object recognition task, for measuring anxiety and for exploration as well as locomotion. An animal taken out from the specialized cage and placed in the center square of the open field apparatus, rats move from the center square, crossing with all four paws, corner, sittings, grooming, gnawing, these all activities scored for $5 \mathrm{~min}$.

The Morris Water Maze (MWM) was used in order to test hippocampal-dependent learning, including acquisition of spatial memory and long term spatial memory. During the Morris water maze test, the rat or mouse learns to escape from the water by locating a hidden platform with the help of visual cues. Optionally, the platform is removed in a second phase of the experiment, or placed in another quadrant, to investigate the animal's response to this new situation or to measure extinction. The forced swim test apparatus consists of a glass cylinder $(20 \mathrm{~cm}$ diameter, $40 \mathrm{~cm}$ tall) filled with water to a depth of $20 \mathrm{~cm}$ and maintained at a room temperature.

At the start of the session, animals are removed from their own home cage and are gently lowered into the apparatus for a $10 \mathrm{~min}$ swim session. Testing may be conducted for a single stress session or repeated over 5 single daily test sessions to determine the anxiety of rats.

\section{Decapitation of rats}

After 3 weeks of injections, rats were decapitated, by a specialized design apparatus, (guillotine). Blood and liver were collected quickly within $30 \mathrm{~s}$ of decapitation stored at low temperature $\left(-70^{\circ} \mathrm{C}\right)$ until analyzed for hematological and biochemical analysis.

\section{Laboratory analysis}

Automated Hematology Analyzer SYSMEX XP 100 and Biochemical analyzer the Roche/Hitachi 902 was used for biochemical and hematological analysis.

\section{Statistical analysis}

Results were represented as mean \pm SD $(n=12)$ significant difference by student $\mathrm{t}$-test $\mathrm{p}<0.01$ level from TG and CG following one-way ANOVA.

\section{Results}

Figure 1a and 1b Panadol extra effects on TG and CG treated rats, in novel environment and home cage activity. Statistical analysis by student $\mathrm{t}$-test $(\mathrm{df} 2,12)(\mathrm{t}=1.5526)(\mathrm{p}>0.01)$ and $(\mathrm{df} 2,12)(\mathrm{T}=8.8117)(* *$ $\mathrm{p}<0.01)$ individual difference by student $t$-test respectively shows that after administration of Panadol extra in TG the Novel Environment behavior decrease as compared to CG while, home cage activity increases as compared to CG.

Figure 1c and 1d shows Panadol extra effects on TG and CG treated rats, in light and dark activity. Statistical analysis by student t-test $(\mathrm{df} 2,12)(\mathrm{T}=1.9336)(\mathrm{p}>0.01)$ and $(\mathrm{df} 2,12)(\mathrm{T}=10.9) \quad\left({ }^{* *} \mathrm{p}<0.01\right)$ individual difference by student $\mathrm{T}$-test shows that after administration of Panadol extra in TG the entries in light portion was increased and rats spend their more time in light portion as compared to CG respectively.

Figure 1e-1g Panadol extra effects on TG and CG treated rats. Statistical analysis by student $\mathrm{t}$-test $(\mathrm{df} 2,12)(\mathrm{T}=56.666)\left({ }^{* *} \mathrm{p}<0.01\right)$, $(\mathrm{df} 2,12)(\mathrm{T}=18.1666)(++\mathrm{p}<0.01)$ and $(\mathrm{df} 2,12)(\mathrm{T}=6.2333)(+\mathrm{p}<0.01)$ individual difference by student $\mathrm{T}$-test shows that after administration of Panadol extra in TG the forced swimming test behavior increases and the water maize activity behavior for short term and long-term memory decreases in TG as compared to CG.

Figure 2a and 2b Panadol extra effects on blood samples on TG and CG treated rats in $\mathrm{Hb} \%$ and RBC. Statistical analysis by student t-test $(\mathrm{df} 2,12) \quad(\mathrm{T}=3.029) \quad(\mathrm{p}>0.01)$ and $(\mathrm{df} 2,12) \quad(\mathrm{T}=3.490) \quad(\mathrm{p}>0.01)$ individual difference by student $\mathrm{T}$-test shows after administration of Panadol extra the HB\% and RBC non-significantly decreases in TG as compare to CG of male rats.

Figure $2 \mathrm{c}-2 \mathrm{e}$ statistical analysis by student t-test $(\mathrm{df} 2,12)(\mathrm{T}=2.890)$ $(\mathrm{p}>0.01), \quad(\mathrm{df} 2,12) \quad(\mathrm{T}=10.985) \quad(++\mathrm{p}<0.01) \quad$ and $(\mathrm{df} 2,12) \quad(\mathrm{T}=41.40)$ $(++p<0.01)$ shows that after administration of Panadol extra, the PCV, $\mathrm{MCV}$ and $\mathrm{MCH}$ are non-significantly decreased in TG as compare to CG respectively.

Figure $2 \mathrm{f}-2 \mathrm{~h}$ statistical analysis by student $\mathrm{t}$-test $(\mathrm{df} 2,12)(\mathrm{T}=0.426)$ $(\mathrm{p}>0.01), \quad(\mathrm{df} 2,12) \quad(\mathrm{T}=15.21) \quad(++\mathrm{p}<0.01) \quad$ and $\quad(\mathrm{df} 2,12) \quad(\mathrm{T}=9.580)$ $(+p=0.01)$ shows after administration of Panadol extra in TG the MCHC has no effect while, TLC and PLT were highly significantly decreased as compare to CG.

Figure 3a-3c statistical analysis by student t-test $(\mathrm{df} 2,12)(\mathrm{T}=848.14)$ $(\mathrm{p}<0.01), \quad(\mathrm{df} 2,12) \quad(\mathrm{T}=829.14) \quad(\mathrm{p}<0.01) \quad$ and $\quad(\mathrm{df} 2,12) \quad(\mathrm{T}=1972.9)$ $(\mathrm{p}<0.01)$ the enzyme AST, LDH and CPK were extremely significantly increases as compare to CG.

\section{Discussion}

Present study shows that Panadol extra has no significant effects on locomotor activity. It has salicylic acid in it which causes subtilize of blood which may be alternatively increases the activeness of rats through which the stimulatory activity of rats also increases day by day. Caffeine in Panadol extra may increase the anxiety but due to the 


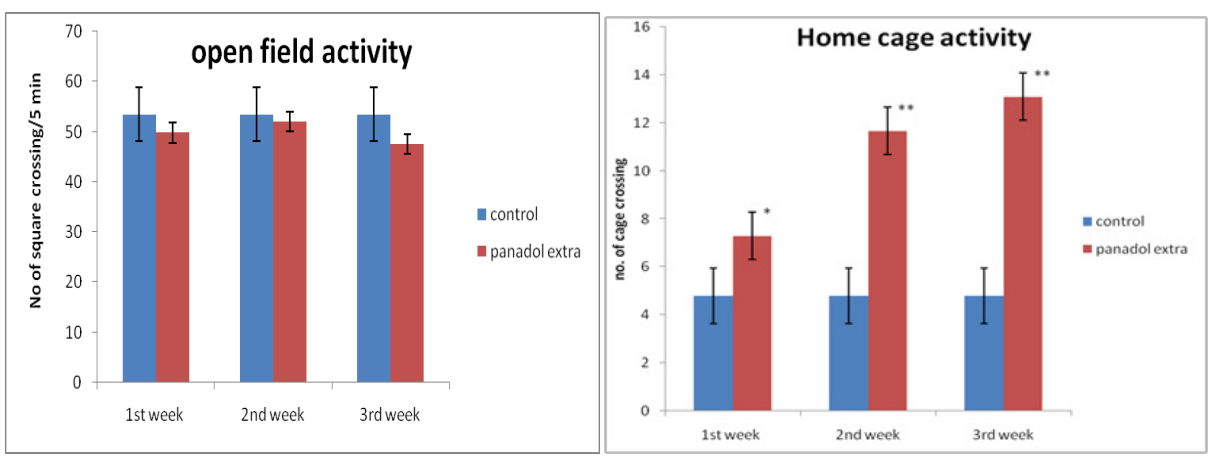

(a)

(b)
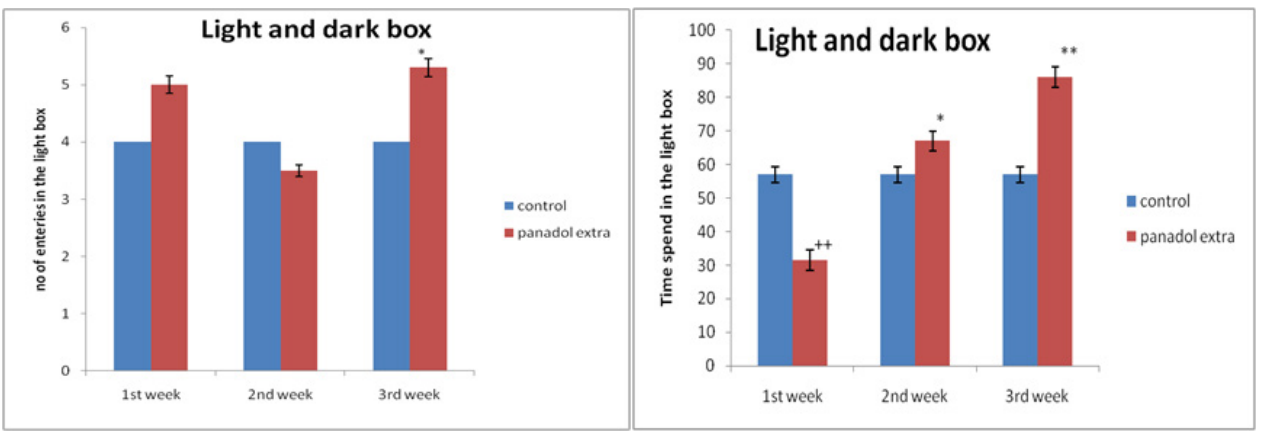

(c)

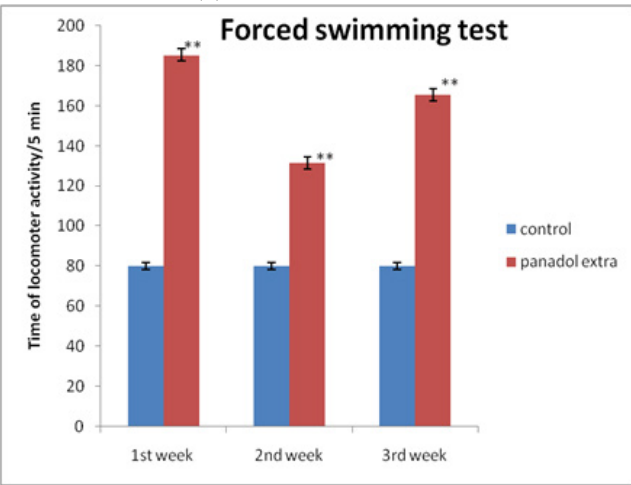

(d)

(e)

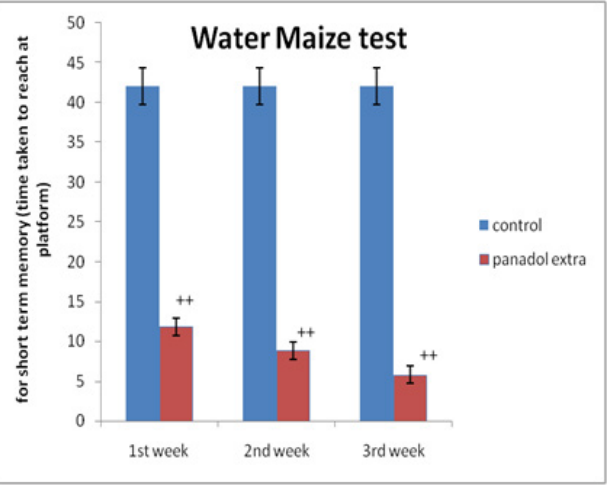

(f)

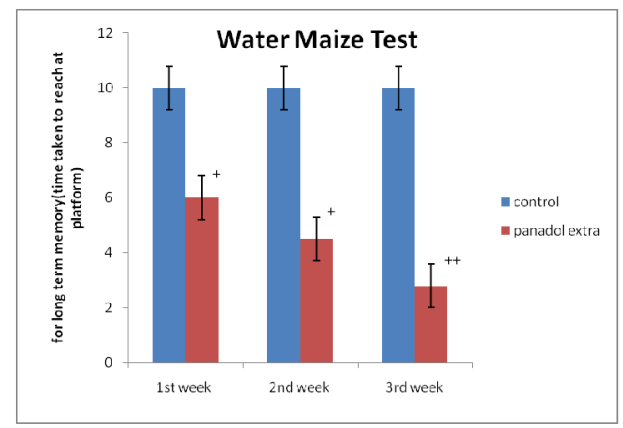

(g)

Figure 1: Determination of behavioral activity. Values are mean $\pm S D(n=12)$ significant difference by student $t$-test $p<0.01$ level from control and test. Behavioral studies including: (a) Open field activity (no. of square crossing); (b) Home cage activity (no. of cage crossing); (c) Light and dark activity (no. of entries in the light box); (d) Light and dark activity (time spend in the light box); (e) Forced swimming activity (time of locomotor activity); (f) Water maize test (for short term memory); and (g) Water maize test (for long term memory). 
Citation: Waris N, Kausar R, Waris N, Naz F, Raza A (2017) Effect of Extra Panadol on Blood and Behavior of Rats. J Bioanal Biomed 9: 206-211. doi:10.4172/1948-593X.1000179

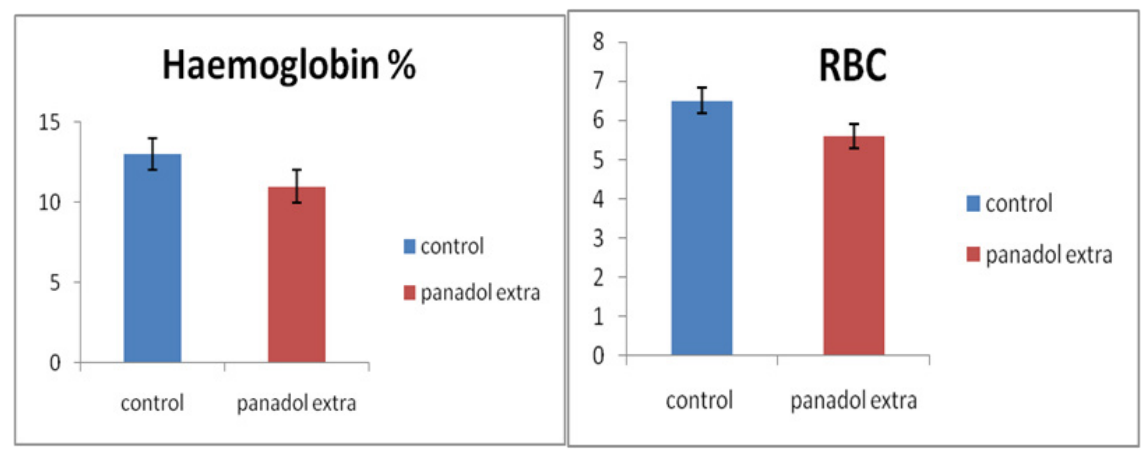

(a)

(b)

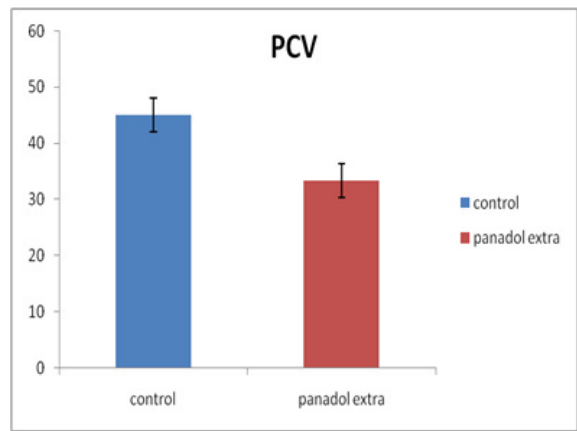

(c)

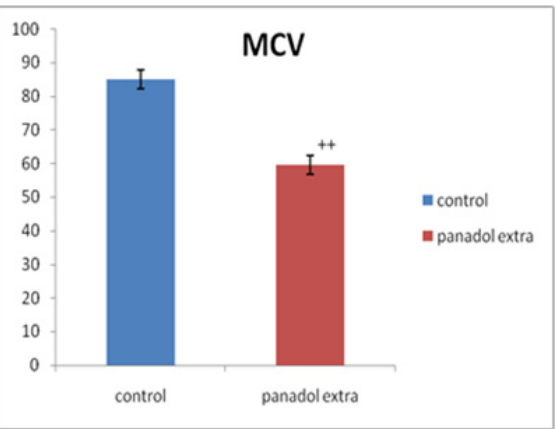

(d)

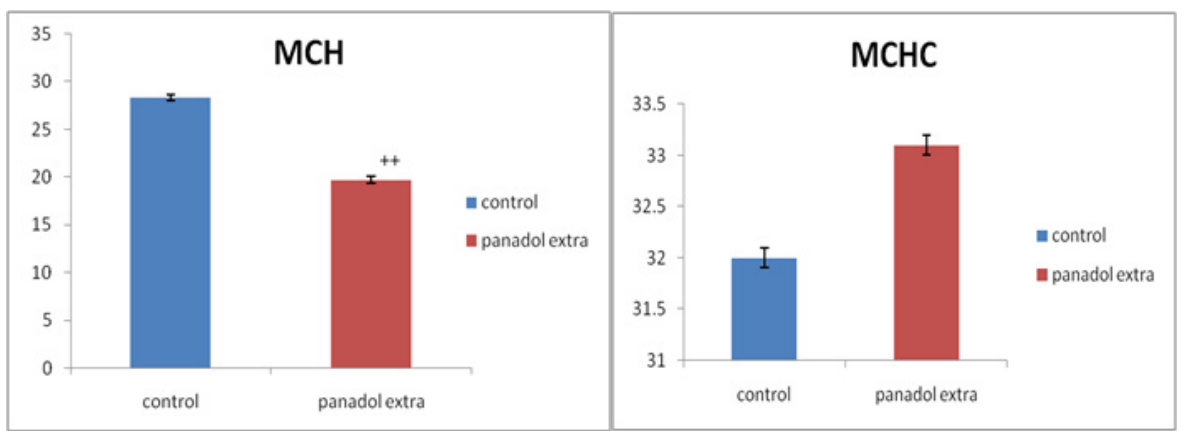

(d)

(f)

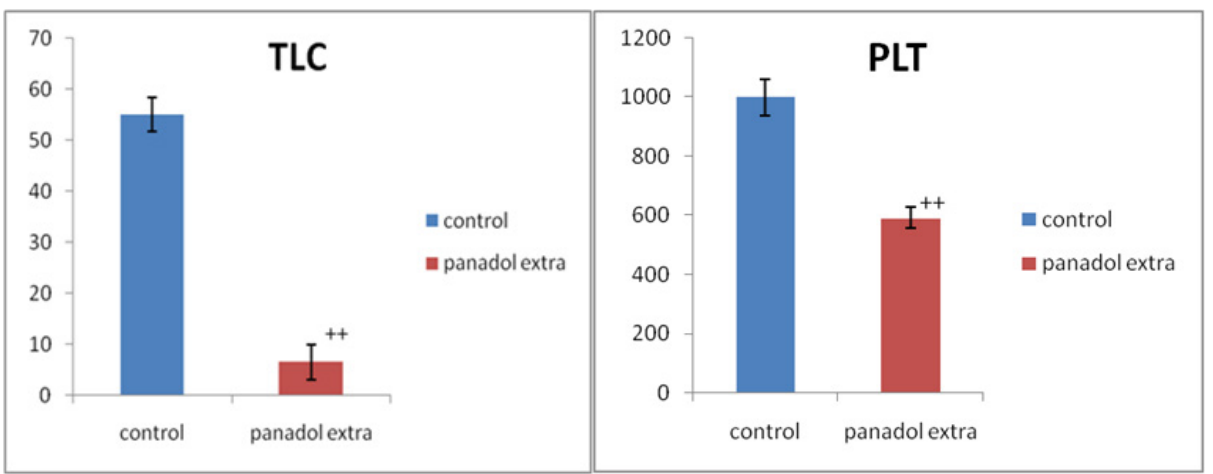

(g)

(h)

Figure 2: Laboratory analysis for hematological parameters. Values are mean $\pm S D(n=12)$ significant difference by student $t$-test $p<0.01$ level from control and test. Hematological parameters including: (a) Hemoglobin percentage (Hb) g/L; (b) red blood cells (RBC) $10^{12}$ cells/L; (c) Packed Cell Volume (PCV) L/L; (d) Mean corpuscular volume (MCV) fL; (e) Mean cell hemoglobin (MCH) pg; (f) Mean corpuscular hemoglobin concentration (MCHC) g/L; (g) Total leucocytes count (TLC) 10\% $/ \mathrm{L}$; and $(\mathrm{h})$ Platelets (PLT) 10\% 
Citation: Waris N, Kausar R, Waris N, Naz F, Raza A (2017) Effect of Extra Panadol on Blood and Behavior of Rats. J Bioanal Biomed 9: $206-211$. doi:10.4172/1948-593X.1000179

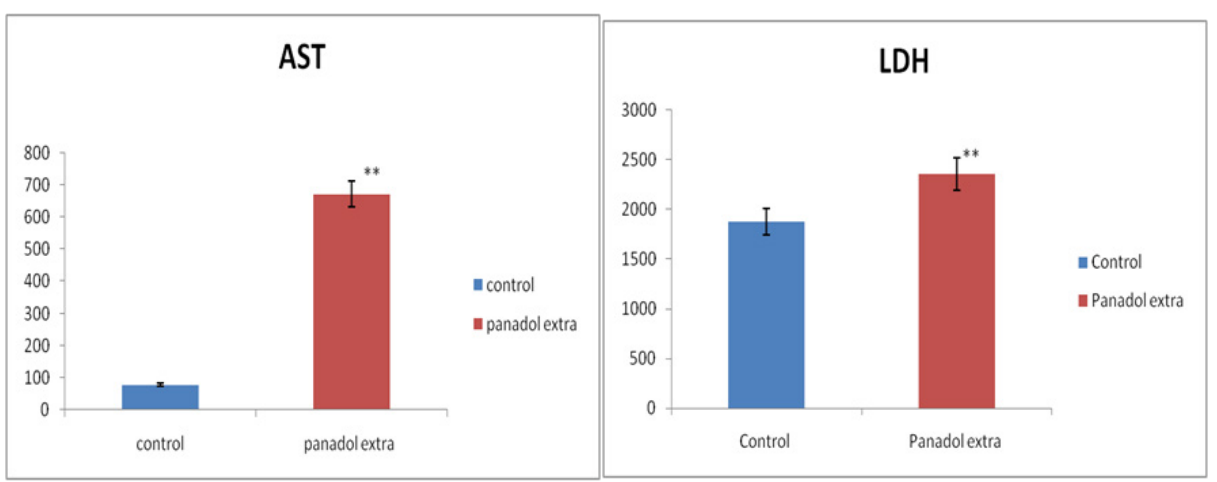

(a)

(b)

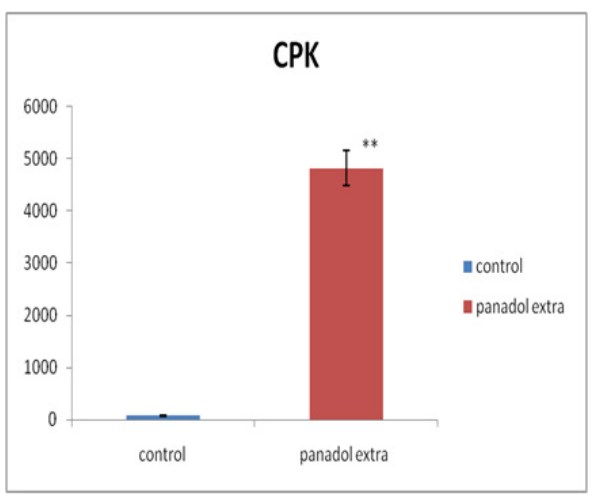

(c)

Figure 3: Laboratory analysis for Liver and Muscles enzymes. Values are mean $\pm S D(n=12)$ significant difference by student t-test $p<0.01$ level from control and test. Liver and muscles enzymes including: (a) Aspartate transaminase (AST) U/L; (b) Lactate dehydrogenase (LDH) U/L; and (c) Creatine phosphokinase $(\mathrm{CPK}) \mathrm{U} / \mathrm{L}$.

presence of paracetamol the anxiety decreases [14]. Low administration of drug increases anxiety but regular administration of drug decreases the anxiety. Caffeine intake and depression may be linked indirectly for people who are particularly sensitive to the effects of caffeine. Results of depression were observed significantly decreased, indicating that rats become undepressed. Laboratory studies show that paracetamol release serotonin, boosting its pain-relieving benefits have an indirect effect on memory by reducing feelings of depression. Previous study shows that paracetamol blocks the activity of an enzyme called cyclooxygenase-2, which stops production of these pain causing by prostaglandins and activate an area of the brain involved in learning, memory and problem-solving called the hippocampus [15].

Hematological parameters including Hemoglobin percentage, red blood cells, packed cell volume, mean corpuscular volume, mean cell hemoglobin, total leucocytes count and platelets were non-significantly decreased as compare to control rats. While, mean corpuscular hemoglobin concentration were highly significantly increased in test group. In response to injury and certain diseases one of the effects of prostaglandins is to sensitize nerve endings, causing pain [16]. As paracetamol reduces the production of these nerves sensitizing prostaglandins but pain threshold may increase. For relieving mild to moderate pain and fever, Paracetamol is known as effective as aspirin or ibuprofen but unlike aspirin and ibuprofen it has no anti-inflammatory effect. Caffeine is not only a mild stimulant that helps to reduce fatigue but also thought to enhance the painkilling effect of paracetamol [17].
As overdose of Panadol extra is dangerous and capable of causing serious damage to the liver and kidneys [18]. Thrombocytopenia (low platelet count) and leukopenia (low number of white blood cells) were also associated with Paracetamol. Mean corpuscular volume (MCV) is a measurement of the average size of RBCs. When the MCV is decreased, RBCs are smaller than normal (microcytic) [19]. MCH is used to help diagnose the type (cause) and severity of anaemia. The $\mathrm{MCHC}$, a measure of the concentration of hemoglobin in a given volume of packed red blood cells. Aspartate aminotransferase was used to detect liver damage in conjunction with another liver enzyme, alanine aminotransferase [20]. Sometimes, AST may be used to monitor people who are taking medications that are potentially toxic to the liver. A lactate dehydrogenase test is a non-specific test for the evaluation of a number of diseases, released from cells into the fluid portion of blood when cells are damaged or destroyed. Thus, the blood level of $\mathrm{LD}$ is a general indicator of tissue and cellular damage. In blood, due to any muscle injury or damage Creatine phosphokinase increases. Inflammation in the muscles also raises the CPK level [21]. Present study shows that the values of CPK, AST and LDH enzymes were highly significantly increases in TG as compare to CG. The increase values of enzymes show that the Panadol extra have adverse effect on liver and tissues of rats. It results might be increases due to decapitation or may be increases due to daily administration of Panadol extra.

By daily administering of Panadol extra to test group rats is considered a useful drug and a good choice of drug because it has 
Citation: Waris N, Kausar R, Waris N, Naz F, Raza A (2017) Effect of Extra Panadol on Blood and Behavior of Rats. J Bioanal Biomed 9: 206-211. doi:10.4172/1948-593X.1000179

salicylic acid in it which is blood thinner but it is useful for a limited period of time. If Panadol extra is used for a long time it has some adverse effects.

\section{Conclusion}

It was concluded in the study that Panadol extra has no effect on locomotor activity and the effect of stimulatory activity of rats increases. Depression and anxiety of rats decreases and at the same time it is useful to enhance memory. Hematological parameters were nonsignificantly decreased in TG while, liver and muscles enzymes were highly significantly increased. In present study, it is considered a good choice of drug if, it is used properly but due to frequent and prolonged or excessive use of Panadol extra rats become unable to Fight against diseases and blood clotting mechanism is highly disturbed. So, the present study concludes that this drug may be used to enhance memory and to decrease anxiety and depression for good performance.

\section{References}

1. Calixto JB, Campos MM, Santos AR (2009) Botanical analgesic and antiinflammatory drugs. Ethnopharmacology 2: 29-36.

2. Bauer R, Woelkart K, Salo-Ahen OM (2008) CB receptor ligands from plants. Curr Top Med Chem 8: 173-186.

3. Rabbani AE (2010) Pharmacology in 7 days for medical students. Radcliffe Publishing

4. Webster $\mathrm{Cl}$, Hatcher J, Burrell M, Thom G, Thornton P, et al. (2017) Enhanced delivery of IL-1 receptor antagonist to the central nervous system as a novel anti-transferrin receptor-IL-1RA fusion reverses neuropathic mechanical hypersensitivity. Pain 158: 660-668.

5. Rhodes LA (2017) 14 Pain Management for Sarcoma Patients. Sarcoma: A Multidisciplinary Approach to Treatment 31: 273.

6. Walco GA, Gove N, Phillips J, Weisman SJ (2017) Opioid Analgesics Administered for Pain on the Inpatient Pediatric Setting. J Pain.

7. Bellieni CV, Tei M, Cornacchione S, Di Lucia S, Nardi V, et al. (2017) Pain perception in NICU: a pilot questionnaire. J Matern Fetal Neonatal Med pp: 1-3.
8. Randall LO (2017) Non-narcotic analgesics. Physiol Pharm 1: 313-416.

9. Tao N, Liu G, Bai L, Tang L, Guo C (2017) Genotoxicity and growth inhibition effects of aniline on wheat. Chemosphere 169: 467-473.

10. Chen F, Hu ZY, Parker RB, Laizure SC (2017) Measurement of caffeine and its three primary metabolites in human plasma by HPLC-ESI-MS/MS and clinical application. Biomed Chromatogr 31: e3900.

11. Uddin MS, Wali MW, Mamun AA, Asaduzzaman M, Amran MS, et al. (2016) Assessment of risk involved in the combination medicine of paracetamol and caffeine. J Adv Med Pharm Sci 5: 1-8.

12. Davis S (2017) A cold or the flu-why is it important to know? SA Pharmacist's Assistant 17: 8-10.

13. Derry S, Wiffen PJ, Moore RA (2017) Aspirin for acute treatment of episodic tension-type headache in adults. Cochrane Database Syst Rev.

14. Sauer AV, Hernandez RJ, Fumagalli F, Bianchi V, Poliani PL, et al. (2017) Alterations in the brain adenosine metabolism cause behavioral and neurological impairment in ADA-deficient mice and patients. Sci Rep 7: 40136

15. Tittarelli R, Pellegrini M, Scarpellini MG, Marinelli E, Bruti V, et al. (2017) Hepatotoxicity of paracetamol and related fatalities. Eur Rev Med Pharmacol Sci 21: 95-101.

16. Ross JA, Greenwood AC, Sasser P, Jiranek WA (2017) Periarticular injections in knee and hip arthroplasty: where and what to inject. J Arthroplasty.

17. Mulka-Gierek M, Foroncewicz B, Florczak M, Pączek L, Krawczyk M, et al. (2016) The use of nonsteroidal anti-inflammatory drugs and analgesics by liver transplant recipients. J Clin Nurs 25: 1001-1005.

18. http://www.netdoctor.co.uk/medicines/aches-and.../panadol-extraparacetamol-and-caffeine/

19. Cascio MJ, DeLoughery TG (2016) Anemia: evaluation and diagnostic tests Med Clin North Am 101: 263-284.

20. Lallukka S, Yki-Järvinen $\mathrm{H}$ (2016) Non-alcoholic fatty liver disease and risk of type 2 diabetes. Best Pract Res Clin Endocrinol Metab 30: 385-395.

21. Punduk Z, Oral O, Ozkayin N, Rahman K, Varol R (2016) Single dose of intramuscular platelet rich plasma reverses the increase in plasma iron levels in exercise-induced muscle damage: A pilot study. J Sport Health Sci 5: 109-114. 